\title{
EFEKTIFITAS PENERAPAN KONSEP SMART CITY DITINJAU DARI ASPEK INDEKS PEMBANGUNAN MANUSIA DI KOTA SEMARANG
}

\author{
Eko Muliawan Satrio, S.T, M.T. ${ }^{1}$ \\ Agus Rochani, S.T, M.T ${ }^{2}$ \\ Prodi Sipil Fakultas Teknik, Universitas Islam Sultan Agung Semarang ${ }^{1}$ \\ Prodi Perencanaan Wilayah \& Kota Fakultas Tenik, Universitas Islam Sultan Agung Semarang ${ }^{2}$ \\ Email Korespondensi : agusplanoo@gmail.com
}

\begin{abstract}
Smart people are the basis of the realization of Smart Cities. This relates to the formation of smart cities, must have intelligent human resources and supported by policies and infrastructure of mobility, governance, economy and environment that are also smart to produce the quality of life as intelligent as desired. Semarang City Government, has been implementing the concept of smart cities since 2013. This travel program is very dynamic in the field. For this reason, it is necessary to consider the effectiveness of the application of the smart city concept by the Semarang City Government to the community. The assessment carried out is by calculating the Human Development Index (HDI) or can also be called the Human Development Index (HDI). Through this evaluation, making information about the application of the Smart Cities concept specifically reviews aspects of human development. ("The process of enlarging people's choices"). Longevity and healthy living, knowledge level and decent standard of living of the community. These findings serve as well as feedback for the implementation of the Smart Cities policy for future policy refinement.
\end{abstract}

Keywords: Human Development Index, intelligence, effectiveness

\begin{abstract}
ABSTRAK
Smart people merupakan dasar dari terwujudnya akan Smart City. Hal ini dikarenakan untuk membentuk suatu kota yang cerdas, harus memiliki sumber daya manusia yang cerdas dan didukung oleh kebijakan dan infrastruktur dari mobility, governance, economy dan environment yang juga cerdas sehingga menghasilkan kualitas hidup yang cerdas seperti yang diinginkan. Pemerintah Kota Semarang, telah menerapkan konsep smart city sejak tahun 2013. Perjalanan program ini sangat dinamis di lapangan. Untuk itu diperlukan penilaian terhadap tingkat efektifitas penerapan konsep smart city oleh Pemerintah Kota Semarang terhadap masyarakat. Pendekatan yang dilakukan adalah dengan menghitung Indeks Pembangunan Manusia (IPM) atau dapat juga disebut Human Development Indeks (HDI). Melalui pendekatan ini, dihasilkan informasi tentang efektivitas penerapan konsep Smart City khususnya ditinjau dari aspek pembangunan manusia. ( " $a$ process of enlarging people's choices"). Adapun variabel yang diukur meliputi Umur panjang dan hidup sehat, tingkat pengetahuan dan standar hidup layak masyarakat. Temuan ini sekaligus berfungsi sebagai feedback bagi pelaksanaan kebijakan Smart City bagi penyempurnaan kebijakan di masa yang akan datang.

Kata kunci : Indeks Pembangunan Manusia, smartcity, efektifitas
\end{abstract}




\section{Pendahuluan \\ 1.1 Latar Belakang}

Smart people adalah salah satu dimensi dari 6 indikator dari perwujudan Smart City yang digagas oleh Boyd Cohen. Dari indikator tersebut, smart people merupakan dasar dari terwujudnya akan Smart City. Hal ini dikarenakan untuk membentuk suatu kota yang cerdas, harus memiliki sumber daya manusia yang cerdas dan didukung oleh kebijakan dan infrastruktur dari mobility, governance, economy dan environment yang juga cerdas sehingga menghasilkan kualitas hidup yang cerdas seperti yang diinginkan.

Pemerintah Kota Semarang, telah menerapkan konsep smart city sejak tahun 2013. Hal ini diwujudkan oleh Pemerintah Kota Semarang dengan terus mengembangkan berbagai inovasi yang berfokus pada peningkatan kemudahan, ketepatan dan kepercayaan masyarakat. Konsep smart yang diterapkan dalam berbagai sistem pelayanan online di Kota Semarang ini meliputi konsep systematic (terhubung sistem), monitorable (dapat dipantau), accessible (mudah diakses), reliable (dapat dipercaya), serta time bound (batasan waktu). Fokus dari konsep smart tersebut adalah upaya pemerintah kota Semarang dalam memberikan kemudahan, ketepatan dan kepercayaan bagi masyarakat.

\subsection{Rumusan Masalah}

Rumusan masalah yang akan di bahas dalam penelitian ini adalah terkait bagaimana efektifitas konsep smart city yang telah diterapkan oleh Pemerintah Kota Semarang terhadap masyarakat. Yakni dari mulainya di terapkannya konsep SMART CITY sampai saat penelitian ini dilakukan.

\subsection{Tujuan dan Sasaran Penelitian}

Tujuan dari penelitian ini adalah mengetahui efektifitas konsep smart city yang telah diterapkan oleh Pemerintah Kota Semarang terhadap masyarakat. Sedangkan sasaran yang ingin dicapai adalah

1) Mengidentifikasi konsep Smart City yang diterapkan oleh Pemerintah Kota Semarang.

2) Mengidentifikasi indeks pembangunan manusia (masyarakat) Kota Semarang, setelah diterapkannya konsep SMART CITY.

3) Mengidentifikasi efektifitas konsep smart city yang telah diterapkan Pemerintah Kota Semarang terhadap masyarakat. 


\section{$1.4 \quad$ Ruang Lingkup}

Ruang lingkup kawasan penelitian yang diambil adalah Kota Semarang sebelum diterapkannya konsep smartcity hingga penelitian ini dibuat (sebelum tahun 2013 dan tahun 2018).

\section{Tinjauan Pustaka}

\subsection{Definisi Smart City dari beberapa ahli}

Menurut Cohen Boyd, yang dimaksud dengan Smart City adalah sebuah pendekatan yang luas, terintegrasi dalam meningkatkan efisiensi pengoperasian sebuah kota, meningkatkan kualitas hidup penduduknya dan menumbuhkan ekonomi daerahnya. Selain itu, Cohen lebih mendifinisikan Smart City dengan pembobotan dari aspek lingkungan menjadi : Smart City menggunakan ICT secara pintar dan efisien dalam menggunakan berbagai sumber daya, menghasilkan penghematan biaya dan energi, meningkatkan pelayanan dan kualitas hidup, serta mengurangi degradasi lingkungan yang nantinya berujung ke dalam inovasi dan ekonomi ramah lingkungan.

Smart city merupakan hasil dari pengembangan pengetahuan yang intensif dan strategi kreatif dalam peningkatan kualitas sosial-ekonomi, ekologi, daya kompetitif kota. Kemunculan smart city merupakan hasil dari gabungan modal sumberdaya manusia (misal angkatan kerja terdidik), modal struktur infrastuktur (misal seperti fasilitas komunikasi yang berteknologi tinggi), modal sosial (seperti jaringan komunikasi yang terbuka) dan modal enterpreuneurial (misalnya seperti aktifitas bisnis kreatif) Kourtit \& Nijkamp (2012). Selain itu Kourtit \& Nijkamp menyebutkan bahwa pemerintahan yang kuat dan dapat dipercaya disertai dengan orang-orang yang kreatif dan berpikiran terbuka akan meningkatkan produktifitas lokal dan mempercepat pertumbuhan ekonomi suatu kota.

Smart City merupakan kota dengan investasi yang dimiliki, yakni terdiri dari modal manusia dan sosial, transportasi dan infrastruktur komunikasi modern serta pembangunan ekonomi yang continue dan kualitas hidup yang tinggi, dengan manajemen sumberdaya alam yang bijaksana melalui tata pemerintahan yang partisipatif. (Giffinger, (2010) dalam Junghoon (2014)).

\subsection{Konsep Smartcity}

Adapun 6 indikator yang membentuk sebuah konsep Smart City, menurut IBM (International Business Machine): (http://smartcityiiuc.blogspot.co.id/)

\section{Smart people}


yaitu modal manusia yang well educated baik secara formal maupun non formal dan terwujud dalam individu atau komunitas-komunitas yang kreatif. Hal tersebut dapat dilihat dari tingkat pendidikan dan pengembangan SDM yang paham akan teknologi. Pengembangan karakter sosial budaya masyarakat yang sejalan dengan tingkat pendidikan masyarakat.

\section{Smart environment}

Yaitu lingkungan yang meberikan kenyamanan dimasa kini dan masa mendatang dengan kata lain berkelanjutan lingkungan baik keadaan fisik maupun non fisik.

\section{Smart governance}

Paradigma pemerintah yang mengeluarkan kebijakan yang mengindahkan prinsipprinsip supermasi hukum, kemanusian, keadilan, demokrasi, partisipasi, transparansi, profesionalitas, dan akuntabilitas serta efektibilitas dan efesiensi kebijakan.

\section{Smart economy}

Yaitu tingginya Perekonomian dan kesejahteraan finansial masyarakat dengan pertumbuhan ekonomi yang baik dan pendapatan perkapita yang tinggi.

\section{Smart mobility}

Yaitu sistem pergerakan yang memungkinkan terjadinya pemenuhan kebutuhan dengan pergerakan seminim mungkin dan secepat mungkin.

\section{Smart living}

Mengacu pada kualitas hidup dan kebudayan masyarakat faktor yang paling mempengaruhi adalah tersedianya kebutuhan-kebutuhan, adanya keamanan, keselamatan, kemudahan dan kenyamanan hidup.

Berdasarkan uraian tersebut diatas, dapat di tunjukkan pada gambar bagan berikut

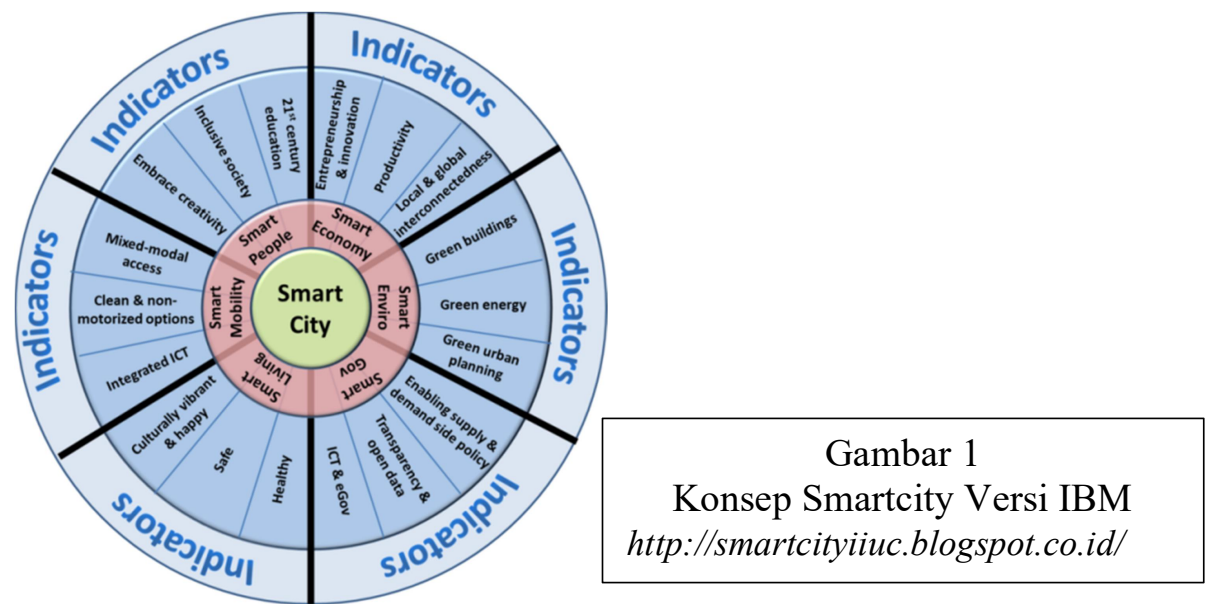




\subsection{Teori Indeks Pembangunan Manusia}

Indeks Pembangunan Manusia (IPM) atau dapat juga disebut Human Development Indeks (HDI) adalah pengukuran perbandingan dari harapan hidup, melek huruf, pendidikan dan standar hidup untuk semua negara seluruh dunia. IPM digunakan untuk mengklasifikasikan sebuah negara, antara lain negara maju, negara berkembang atau negara terbelakang. Selain itu, IPM juga untuk mengukur pengaruh dari kebijakan ekonomi terhadap kualitas hidup. Dalam UNDP (United Nations Development Programme), pembangunan manusia adalah suatu proses untuk memperbesar pilihanpilihan bagi manusia ("a process of enlarging people's choices”). Konsep pembangunan dari UNDP, pembangunan manusia pada dasarnya mencakup dimensi pembangunan yang sangat luas. Pembangunan seharusnya dianalisis serta dipahami dari sudut manusianya, bukan hanya dari pertumbuhan ekonominya.

IPM, dibentuk oleh 3 dimensi dasar, antara lain :

1. Umur panjang dan hidup sehat (a long and healthy life)

1. Pengetahuan (knowledge)

2. Standar hidup layak (decent standard of living)

Manfaat dari Indeks Pembangunan Manusia (IPM), antara lain adalah sebagai berikut:

1 Merupakan indikator penting untuk mengukur keberhasilan dalam upaya membagun kualitas hidup manusia (masyarakat/penduduk).

2 Menentukan peringkat atau level pembangunan suatu wilayah/negara

3 Bagi negara Indonesia, IPM merupakan data strategis karena selain sebagai ukuran kinerja Pemerintah, IPM juga digunakan sebagai salah satu alokator penentuan Dana Alokasi Umum (DAU).

\subsection{Cara Menghitung Indeks Komponen}

Setiap komponen IPM distandardisasi dengan nilai minimum dan maksimum sebelum digunakan untuk menghitung IPM. Perhitungan indeks komponen meliputi dimensi kesehatan, dimensi pendidikan dan dimensi pengeluaran.

\subsubsection{Cara menghitung Indeks Pembangunan Manusia (IPM)}

IPM dihitung sebagai rata-rata geometrik dari indeks kesehatan, pendidikan dan pengeluaran. Rumus perhitungan IPM dapat disajikan sebagai berikut: 
$I P M=\sqrt[3]{\text { I kesehatan } x \text { I pendidikan } x \text { I pengeluaran }} \times 100$

Keterangan :

I kesehatan : Indeks harapan hidup

I pendidikan : Indeks pendidikan yang meliputi indeks RLS dan indeks HLS

I pengeluaran : Indeks standar hidup layak

\subsubsection{Besaran Skala IPM}

Pengklasifikasian pembangunan manusia bertujuan untuk mengorganisasikan wilayah-wilayah menjadi kelompok-kelompok yang sama dalam hal pembangunan manusia. BPS mengklasifikasikan capaian IPM, dapat dikategorikan menjadi 4 tingkatan, antara lain adalah sebagai berikut:

1. IPM sangat tinggi, apabila $I P M \geq 80,00$

2. IPM tinggi, apabila nilai IPM $70 \leq$ IPM $<80$

3. IPM menengah, apabila nilai IPM $60 \leq$ IPM $<70$

4. IPM rendah, apabila nilai IPM $<60$

\subsubsection{Mengukur Kecepatan IPM}

Untuk mengukur kecepatan perkembangan IPM dalam suatu kurun waktu digunakan ukuran pertumbuhan IPM per tahun. Pertumbuhan IPM, menunjukkan perbandingan antara capaian yang telah ditempuh dengan capain sebelumnya. Semakin tinggi nilai pertumbuhan, semakin cepat IPM suatu wilayah untuk mencapai nilai maksimalnya.

$$
\text { Pertumbuhan } I P M=\frac{I P M t-I P M t-1}{I P M t-1} \times 100
$$

IPM $\mathrm{t}_{\mathrm{t}} \quad$ : IPM suatu wilayah pada tahun $\mathrm{t}$

IPM $_{\mathrm{t}-1} \quad$ : IPM suatu wilayah pada tahun $(\mathrm{t}-1)$

\section{Hasil dan Pembahasan}

\subsection{Penerapan Smartcity Kota Semarang}

Masterplan Smartcity Kota Semarang diatur dalam Peraturan Walikota Semarang nomor 26 tahun 2018. Pada peraturan tersebut berisi tentang ruang lingkup Rencana Induk Semarang Kota Cerdas, Rencana Induk Semarang Kota Cerdas (Masterplan Semarang 
Smart city), dan pembiayaan dalam Rencana Induk Semarang Kota Cerdas. Kedudukan Masterplan Semarang Kota Cerdas adalah sebagai pedoman bagi Pemerintah Kota Semarang dan pemangku kepentingan pembangunan kota dalam:

a. Penyusunan dokumen perencanaan, pelaksanaan, pengendalian, monitoring, evaluasi dan pelaporan pembangunan, dan

b. Koordinasi dan sinkronisasi pembangunan daerah dari berbagai pihak.

Demi mensukseskan visi dan misi Smartcity di Kota Semarang, pemerintah daerah menerapkan program quick wins. Penerapan program quick wins, diharapkan dapat memberikan dampak positif jangka pendek yang dapat dirasakan oleh masyarakat. Quick wins utama dalam program smartcity Kota Semarang tertuang pada RPJMD periode 20162021. Adapun quick wins tersebut, antara lain adalah sebagai berikut :

1. Berbasis TI. Yakni pemandu lokasi berbasis smartphone "Semarang dalam genggaman".

2. Berbasis non TI. Yakni pusat informasi publik Kota Semarang '3 in 1 layanan publik'

Adapun program quick wins yang dilakukan oleh pemerintah daerah beserta pemangku kepentingan pembangunan Kota Semarang, dapat diperlihatkan pada tabel berikut di bawah ini.

Tabel 1

Program Quick Wins Smartcity Kota Semarang

\begin{tabular}{|c|c|c|c|}
\hline No & Bentuk & Quick Win & OPD \\
\hline 1 & $\begin{array}{l}\text { Smart } \\
\text { governance }\end{array}$ & $\begin{array}{l}\text { Integrasi sim perencanaan-keuangan- } \\
\text { monev-pelaporan }\end{array}$ & Semua OPD \\
\hline 2 & $\begin{array}{l}\text { Smart } \\
\text { branding }\end{array}$ & $\begin{array}{l}\text { Pemandu lokasi berbasis smartphone } \\
\text { "Semarang dalam genggaman". }\end{array}$ & $\begin{array}{l}\text { DISBUDPAR, DISKOMINFO, } \\
\text { Bag. TAPEM, Bag. Ekonomi, } \\
\text { DISDIK, DINKES, Bag. } \\
\text { KESRA, BAPPEDA }\end{array}$ \\
\hline 3 & $\begin{array}{l}\text { Smart } \\
\text { economy }\end{array}$ & $\begin{array}{l}\text { Pemberian kredit wibawa: tanpa } \\
\text { agunan bagi UKM }\end{array}$ & $\begin{array}{l}\text { PD. Bank pasar, dinkopukm, } \\
\text { bag. Ekonomi, disperin, dindag }\end{array}$ \\
\hline 4 & Smart living & $\begin{array}{l}\text { Info listrik padam \& hidup serta } \\
\text { penyebabnya di Wilayah Semarang }\end{array}$ & $\begin{array}{l}\text { DISTARU, DISPERKIM, } \\
\text { DISKOMINFO, DPU }\end{array}$ \\
\hline 5 & Smart society & $\begin{array}{l}\text { Pusat layanan informasi publik, } 3 \\
\text { layanan dalam } 1\end{array}$ & Semua OPD \\
\hline 6 & $\begin{array}{l}\text { Smart } \\
\text { environment }\end{array}$ & $\begin{array}{l}\text { Penggunaan energi rumah tangga \& } \\
\text { warung makan dari sampah }\end{array}$ & $\begin{array}{l}\text { DISPERKIM, } \\
\text { BAPPEDA, DISTARU, DPU. }\end{array}$ \\
\hline
\end{tabular}

Sumber: Lampiran Perwal Kota Semarang no 26 tahun 2018

\subsection{Realisasi Penerapan Smartcity Dilihat Dari Sudut Pandang Masyarakat Kota Semarang}

Realisasi penerapan konsep smartcity diukur melalui kuesioner yang di sebarkan kepada masyarakat yang ada di Kota Semarang. Kuesioner ini menampilkan pertanyaan 
sekitar program yang diterapkan pemerintah Kota Semarang sampai tahun 2018 saja.

Adapun rangkuman hasil kuesioner tersebut adalah sebagai berikut di bawah ini.

Tabel 2 Hasil Kuesioner Tentang Pendapat Masyarakat Mengenai Program Smartcity yang Diterapkan Di Kota Semarang Sampai Tahun 2018

\begin{tabular}{|c|c|c|c|c|}
\hline \multirow{3}{*}{ No } & \multirow{3}{*}{$\begin{array}{l}\text { Program yang sudah diimplementasikan pemerintah } \\
\text { selama ini (2017-2018) }\end{array}$} & \multicolumn{3}{|c|}{$\begin{array}{l}\text { Pengetahuan Masyarakat tentang } \\
\text { program smartcity }\end{array}$} \\
\hline & & $\begin{array}{l}\text { Sekedar } \\
\text { tau }\end{array}$ & $\begin{array}{l}\text { Sebagai } \\
\text { pengguna } \\
\text { (user) }\end{array}$ & $\begin{array}{l}\text { Tidak tau } \\
\text { sama } \\
\text { sekali }\end{array}$ \\
\hline & & $\%$ & $\%$ & $\%$ \\
\hline $\mathbf{A}$ & Smart Government & & & \\
\hline 1 & Aplikasi analisa Jabatan (AJAB) & 3 & 1 & 99 \\
\hline 2 & Aplikasi penilaian kinerja penyedia & 87 & 4 & 9 \\
\hline 3 & Aplikasi sisa kemampuan paket & 0 & 1 & 99 \\
\hline 4 & Aplikasi surat perjalanan dinas. & 22 & 3 & 75 \\
\hline 5 & Aplikasi web monitoring laporan sampah online & 21 & 1 & 78 \\
\hline 6 & BLC (pusat pembelajaran) & 47 & 34 & 19 \\
\hline 7 & E-Katalog & 41 & 41 & 18 \\
\hline 8 & E-Legislasi & 22 & 1 & 77 \\
\hline 9 & E-Risalah & 22 & 1 & 77 \\
\hline 10 & E-Sakip (siap sakip Kota Semarang) & 81 & 1 & 18 \\
\hline 11 & E-Sarapan & 81 & 1 & 18 \\
\hline 12 & E-Tilang & 0 & 91 & 9 \\
\hline 13 & Integrasi e-reporting-SPP \& SPM-SIM monev & 81 & 1 & 18 \\
\hline 14 & $\begin{array}{lll}\begin{array}{l}\text { Integrasi } \\
\text { pelaporan. }\end{array} & \text { SIM perencanaan-Keuangan-monev- } \\
\end{array}$ & 22 & 1 & 77 \\
\hline 15 & Integrasi SIMPERDA-SIMKEUDA & 22 & 1 & 77 \\
\hline 16 & Integrasi SIRUP - SPSE - e-Katalog & 22 & 1 & 77 \\
\hline 17 & Layanan arsip berbasis online & 0 & 100 & 0 \\
\hline 18 & $\begin{array}{l}\text { Layanan elektronik (e service) adminduk berbasis } \\
\text { WEB, aplikasi pendaftaran online ( } 2 \text { jenis layanan: } \\
\text { akta kelahiran dan akta kematian) }\end{array}$ & 0 & 100 & 0 \\
\hline 19 & Layanan informasi publik & 0 & 91 & 9 \\
\hline 20 & $\begin{array}{l}\text { Layanan integrasi adminisrasi kependudukan dengan } \\
177 \text { kelurahan (offline), SI ATLAS }\end{array}$ & 0 & 100 & 0 \\
\hline 21 & Layanan surat berbasis online se-Kota Semarang. & 81 & 1 & 18 \\
\hline 22 & Pantauan Pendapatan BRT real time & 11 & 1 & 88 \\
\hline 23 & Pelayanan KB di perusahaan & 0 & 1 & 99 \\
\hline 24 & Pelayanan e-tax (parkir, restaurant, hotel). & 0 & 100 & 0 \\
\hline 25 & Pelayanan fasilitas berbasis IT & 0 & 100 & 0 \\
\hline 26 & $\begin{array}{l}\text { Pembebasan PBB bagi masyarakat tidak mampu dan } \\
\text { NJOP di bawah } 130 \text { juta }\end{array}$ & 69 & 31 & 0 \\
\hline 27 & \begin{tabular}{|llll} 
Pemberian hak akses dan pemanfaatan NIK, data \\
kependudukan dan KTP elektronik kepada & 210 \\
lembaga pengguna. & & &
\end{tabular} & 0 & 100 & 0 \\
\hline 28 & Penerapan aplikasi e-PBB online & 49 & 36 & 15 \\
\hline 29 & Penertiban parkir & 0 & 100 & 0 \\
\hline 30 & Pengelolaan Layanan Kepegawaian & 77 & 1 & 22 \\
\hline 31 & Pengembangan E-Musrenbang & 77 & 1 & 22 \\
\hline 32 & Pengembangan E-Pokir & 26 & 65 & 9 \\
\hline 33 & Pengembangan Komunikasi Informasi dan Media & 0 & 100 & 0 \\
\hline
\end{tabular}




\begin{tabular}{|c|c|c|c|c|}
\hline \multirow{3}{*}{ No } & \multirow{3}{*}{$\begin{array}{l}\text { Program yang sudah diimplementasikan pemerintah } \\
\text { selama ini }(2017-2018)\end{array}$} & \multicolumn{3}{|c|}{$\begin{array}{c}\text { Pengetahuan Masyarakat tentang } \\
\text { program smartcity }\end{array}$} \\
\hline & & $\begin{array}{l}\text { Sekedar } \\
\text { tau }\end{array}$ & $\begin{array}{l}\text { Sebagai } \\
\text { pengguna } \\
\text { (user) }\end{array}$ & $\begin{array}{l}\text { Tidak tau } \\
\text { sama } \\
\text { sekali }\end{array}$ \\
\hline & & $\%$ & $\%$ & $\%$ \\
\hline & Masa & & & \\
\hline 34 & Pengembangan Musrembang melalui online & 15 & 12 & 73 \\
\hline 35 & Pengembangan SSR (Single System Report). & 22 & 1 & 77 \\
\hline 36 & $\begin{array}{l}\text { Pengembangan WEB Service Kependudukan dan } \\
\text { DPMPTSP }\end{array}$ & 90 & 1 & 9 \\
\hline 37 & \begin{tabular}{|llll} 
Pengembangan Website dengan Modal GIS dan \\
Aplikasi Berbasis WEB
\end{tabular} & 58 & 24 & 18 \\
\hline 38 & Penyiapan penyusunan Layanan Kepegawaian & 15 & 1 & 84 \\
\hline 39 & $\begin{array}{l}\text { Penyiapan Program Pembebasan } \\
\text { Masyarakat Tidak Mampu }\end{array}$ & 69 & 31 & 0 \\
\hline 40 & Penyusunan dan Pemantapan Program E Katalog Lokal & 90 & 1 & 9 \\
\hline 41 & Penyusunan Grand Design dan DED Minapolitan & 22 & 12 & 66 \\
\hline 42 & Persiapan E-SPTPD dan E-BPHTB online & 22 & 1 & 77 \\
\hline 43 & Persiapan monitoring Pendataan Online & 100 & 0 & 0 \\
\hline 44 & Persiapan payment Gateway pajak daerah & 82 & 0 & 18 \\
\hline 45 & Persiapan penyusunan Layanan Kepegawaian & 1 & 0 & 99 \\
\hline 46 & $\begin{array}{l}\text { Persiapan SI ARPPAD (Siap Armada Pelayanan Pajak } \\
\text { Daerah) }\end{array}$ & 63 & 22 & 15 \\
\hline 47 & $\begin{array}{l}\text { Pertukaran buku (Semarang Book } \text { Exchange) } \\
\text { mendorong masyarakat agar buku lama bisa } \\
\text { dimanfaatkan oleh orang lain yang membutuhkan }\end{array}$ & 59 & 23 & 18 \\
\hline 48 & Program pengentasan kemiskinan & 53 & 47 & 0 \\
\hline 49 & $\begin{array}{l}\text { Seleksi JPT pratama menggunakan CAT (computer } \\
\text { asisstend test) }\end{array}$ & 22 & 1 & 77 \\
\hline 50 & $\begin{array}{l}\begin{array}{l}\text { Sertifikasi kampung } \\
\text { kependudukan }\end{array} \text { Kota } \\
\text { semar/SMS). }\end{array}$ & 15 & 1 & 84 \\
\hline 51 & Si komplit (sistem rekomendasi ijin penelitian) & 44 & 22 & 34 \\
\hline 52 & SIM kerjasama & 22 & 12 & 66 \\
\hline 53 & $\begin{array}{l}\text { Sistem informasi kepegawaian berbasis teknologi } \\
\text { single on (SIMPATIK) }\end{array}$ & 15 & 1 & 84 \\
\hline 54 & Sistem Kendali Lalu lintas kendaraan (ATCS) & 99 & 1 & 0 \\
\hline 55 & Sistem monitoring pendapatan (pajak) online & 77 & 1 & 22 \\
\hline 56 & Tes ujian mutasi masuk menggunakan CAT. & 77 & 1 & 22 \\
\hline 57 & $\begin{array}{l}\text { Tes ujian pemilihan pegawai teladan menggunakan } \\
\text { CAT }\end{array}$ & 77 & 1 & 22 \\
\hline 58 & TV informasi DPRD & 22 & 1 & 77 \\
\hline 59 & TV parlemen & 22 & 1 & 77 \\
\hline 60 & Uji coba penggunaan e katalog lokal & 70 & 22 & 18 \\
\hline 61 & Website/portal bagian organisasi & 50 & 32 & 18 \\
\hline 62 & Wifi di area publik & 19 & 73 & 8 \\
\hline B & Smart Branding & & & \\
\hline 1. & Aplikasi moovit & 23 & 22 & 33 \\
\hline 2 & BRT trans Semarang & 33 & 67 & 0 \\
\hline 3 & Kampung Batik & 24 & 76 & 0 \\
\hline 4. & Kampung jajan pasar & 60 & 40 & 0 \\
\hline
\end{tabular}




\begin{tabular}{|c|c|c|c|c|}
\hline \multirow{3}{*}{ No } & \multirow{3}{*}{$\begin{array}{l}\text { Program yang sudah diimplementasikan pemerintah } \\
\text { selama ini }(2017-2018)\end{array}$} & \multicolumn{3}{|c|}{$\begin{array}{c}\text { Pengetahuan Masyarakat tentang } \\
\text { program smartcity }\end{array}$} \\
\hline & & $\begin{array}{l}\text { Sekedar } \\
\text { tau }\end{array}$ & $\begin{array}{l}\text { Sebagai } \\
\text { pengguna } \\
\text { (user) }\end{array}$ & $\begin{array}{c}\text { Tidak tau } \\
\text { sama } \\
\text { sekali }\end{array}$ \\
\hline & & $\%$ & $\%$ & $\%$ \\
\hline 5 & Kampung pelangi & 0 & 100 & 0 \\
\hline 6 & Pembuatan ruang BLC & 75 & 4 & 32 \\
\hline 7 & Penataan dan pengembangan desa wisata & 97 & 16 & 9 \\
\hline 9 & Penataan desa wisata Kandri & 79 & 23 & 9 \\
\hline 10 & Penataan kampung tematik & 47 & 46 & 7 \\
\hline 11 & Penataan PKL & 99 & 2 & 0 \\
\hline 12 & Semarang night carnival & 5 & 95 & 0 \\
\hline 13 & Ticketing BRT non cash & 60 & 44 & 3 \\
\hline $\mathbf{C}$ & Smart Economy & & & \\
\hline 1 & $\begin{array}{l}\text { Gerbang hebat (gerakan bersama penanggulangan } \\
\text { kemiskinan dan pengangguran). }\end{array}$ & 60 & 22 & 18 \\
\hline 2 & I-Jus Melon & 66 & 16 & 18 \\
\hline 3 & Pelatihan kemandirian kerja & 79 & 12 & 9 \\
\hline 4 & Sarana informasi yang dapat diakses masyarakat & 0 & 95 & 5 \\
\hline 5 & Pelatihan berkompetensi pangsa pasar kerja & 37 & 45 & 18 \\
\hline D & Smart Living & & & \\
\hline 1 & Ambulance hebat & 53 & 47 & 0 \\
\hline 2 & Halo dok & 49 & 46 & 9 \\
\hline 3 & Informasi ketersediaan tempat tidur rumah sakit & 47 & 31 & 22 \\
\hline 4 & $\begin{array}{l}\text { Informasi ketersediaan tempat tidur rumah sakit dan } \\
\text { puskesmas berbasis mobile }\end{array}$ & 47 & 31 & 22 \\
\hline 5 & $\begin{array}{l}\text { Interkoneksi rujukan pasien puskesmas dengan rumah } \\
\text { sakit }\end{array}$ & 65 & 32 & 3 \\
\hline 6 & Pendaftaran antrian puskesmas secara online & 43 & 35 & 22 \\
\hline 7 & Aplikasi bus trans & 48 & 30 & 22 \\
\hline 8 & Bedah rumah tidak layak huni. & 99 & 1 & 0 \\
\hline 9 & Jarik majid (bersih-bersih masjid) & 44 & 56 & 0 \\
\hline 10 & \begin{tabular}{|lll}
$\begin{array}{l}\text { Pemandu lokasi berbasis } \\
\text { terdaftar }\end{array}$ & smartphone/pencaker \\
\end{tabular} & 45 & 33 & 22 \\
\hline 11 & Pembangunan SPAM Semarang Barat. & 24 & 1 & 75 \\
\hline 12 & $\begin{array}{l}\text { Peningkatan kualitas infrastruktur perumahan dan } \\
\text { kawasan permukiman. }\end{array}$ & 66 & 25 & 9 \\
\hline 13 & Rumah duta revolusi mental & 37 & 0 & 63 \\
\hline 14 & Semarang Digital Kreatif. & 22 & 24 & 54 \\
\hline 15 & Simgasurkes & 90 & 1 & 9 \\
\hline 16 & Universal Health Coverage (UHC) & 45 & 46 & 9 \\
\hline $\mathbf{E}$ & Smart Society & & & \\
\hline 1 & Pusat Pelayanan informasi publik, 3 layanan dalam 1 & 0 & 100 & 0 \\
\hline 2 & 1 kelurahan 1 tenaga IT & 99 & 1 & 0 \\
\hline 3 & APBS on-line berbasis tahun anggaran. & 45 & 5 & 50 \\
\hline 4 & Aplikasi penerimaan peserta didik & 37 & 63 & 0 \\
\hline 5 & E-learning & 0 & 91 & 9 \\
\hline 6 & Kampung KB & 73 & 27 & 0 \\
\hline 7 & Laboratorium dapodik & 0 & 100 & 0 \\
\hline 8 & Layanan kartu AK-1 sistem antrian & 0 & 100 & 0 \\
\hline 9 & Pembuatan aplikasi panic button & 44 & 47 & 9 \\
\hline
\end{tabular}




\begin{tabular}{|c|c|c|c|c|}
\hline \multirow{3}{*}{ No } & \multirow{3}{*}{$\begin{array}{l}\text { Program yang sudah diimplementasikan pemerintah } \\
\text { selama ini }(2017-2018)\end{array}$} & \multicolumn{3}{|c|}{$\begin{array}{c}\text { Pengetahuan Masyarakat tentang } \\
\text { program smartcity }\end{array}$} \\
\hline & & $\begin{array}{l}\text { Sekedar } \\
\text { tau }\end{array}$ & $\begin{array}{l}\text { Sebagai } \\
\text { pengguna } \\
\text { (user) }\end{array}$ & $\begin{array}{c}\text { Tidak tau } \\
\text { sama } \\
\text { sekali }\end{array}$ \\
\hline & & $\%$ & $\%$ & $\%$ \\
\hline 10 & Penerimaan peserta didik (PPD) online & 30 & 70 & 0 \\
\hline 11 & Sang juara & 55 & 45 & 0 \\
\hline 12 & Sekolah gratis & 30 & 70 & 0 \\
\hline 13 & Sekolah inklusi & 99 & 1 & 0 \\
\hline 14 & Sekolah model & 45 & 22 & 33 \\
\hline 15 & Semarang mengajar (semarang knowledge sharing) & 47 & 35 & 18 \\
\hline 16 & Smart security (crime) & 70 & 21 & 9 \\
\hline 17 & Instalasi air bersih untuk daerah kekeringan & 60 & 24 & 0 \\
\hline 18 & Lapor Hendi (online) & 22 & 78 & 0 \\
\hline 19 & Layanan perpustakaan berbasis online & 22 & 15 & 63 \\
\hline 20 & Pembangunan sumur resapan. & 58 & 1 & 40 \\
\hline 21 & Penyediaan wifi super cepat bagi masyarakat & 30 & 61 & 9 \\
\hline 22 & Pusat informasi pendidikan. & 0 & 100 & 0 \\
\hline 23 & Sekolah hijau & 0 & 100 & 0 \\
\hline 24 & Sekolah olahraga dan seni. & 0 & 100 & 0 \\
\hline 25 & Sekolah/kursus hebat. & 40 & 22 & 38 \\
\hline 26 & Semarang Digital class (SDC). & 45 & 55 & 0 \\
\hline 27 & Semarang digital kreatif & 22 & 24 & 54 \\
\hline 28 & $\begin{array}{l}\text { Semarang untuk Indonesia : bangunan fisik bagi } \\
\text { transmigrasi asal Kota Semarang }\end{array}$ & 75 & 0 & 25 \\
\hline 29 & Smart Community development & 81 & 1 & 18 \\
\hline $\mathbf{F}$ & Smart Environment & & & \\
\hline 1 & Pengadaan jamban & 57 & 25 & 18 \\
\hline 2 & Mengurangi penggunaan kertas (papperlest) & 48 & 30 & 22 \\
\hline 3 & Normalisasi aliran sungai & 80 & 20 & 0 \\
\hline 4 & Pembangunan kolam retensi. & 94 & 1 & 5 \\
\hline 5 & Pengendalian banjir & 27 & 68 & 5 \\
\hline 6 & $\begin{array}{l}\text { Penggunaan energi rumah tangga dan warung makan } \\
\text { dari sampah }\end{array}$ & 57 & 25 & 18 \\
\hline 7 & $\begin{array}{llll}\begin{array}{l}\text { Pengurangan } \\
\text { (PRBBK) }\end{array} & \text { resiko bencana } & \text { berbasis } & \text { komunitas } \\
\end{array}$ & 22 & 1 & 77 \\
\hline 8 & $\begin{array}{l}\text { Perbaikan jalan pedestrian dan street furniture di } \\
\text { lingkungan }\end{array}$ & 100 & 1 & 0 \\
\hline 9 & \begin{tabular}{|lllll}
$\begin{array}{l}\text { Perbaikan saluran untuk ekologi (saluran untuk } \\
\text { budidaya ikan). }\end{array}$ & & & & \\
\end{tabular} & 52 & 26 & 22 \\
\hline 10 & Pompa air portable & 99 & 1 & 0 \\
\hline 11 & Smart lighting/PJU pintar. & 91 & 0 & 9 \\
\hline 12 & Web GIS inventarisasi pohon & 22 & 1 & 77 \\
\hline 13 & Web GIS pemakaman. & 22 & 12 & 66 \\
\hline & TOTAL & $46.7 \%$ & $31,5 \%$ & $25,5 \%$ \\
\hline
\end{tabular}

Sumber : Kuesioner, 2018

Hasil data kuesioner berdasarkan yang telah dilakukan, dapat diketahui bahwa 46,7 $\%$ masyarakat telah mengetahui mengenai implementasi yang dilakukan oleh Pemerintah Kota Semarang. Perbedaan prosentase pada masyarakat sebagai user dan masyarakat yang 
tidak mengetahui adanya program yang telah diterapkan oleh pemerintah adalah $6 \%$. Dimana $31,5 \%$ responden adalah sebagai pengguna (user) dari beberapa program yang telah diterapkan oleh pemkot.

Sedangkan 25,5\% merupakan sebagian masyarakat yang tidak mengetahui adanya beberapa program Kota Semarang menuju cerdas (smartcity). Hal tersebut terjadi, karena dalam hal ini masyarakat yang memberikan responden tersebut (memilih menjawab sekedar tahu) tidak langsung berkepentingan terhadap program terkait. Selain alasan tersebut diatas, mereka lebih memprioritaskan kebutuhan untuk hidup yakni mencari nafkah bagi keluarganya. Meskipun program tersebut, sebenarnya meningkatkan taraf hidup masyarakat.

\subsection{Perkembangan Indeks Pembangunan Manusia di Kota Semarang Selama Program Smartcity Diterapkan}

Berikut peneliti melampirkan data IPM Kota Semarang dari tahun dimana Kota Semarang baru menerapkan SMARTCITY (2013) sampai dengan tahun 2018.

Tabel 3 Perkembangan IPM Kota Semarang dari Tahun 2013-2018

\begin{tabular}{|l|l|l|l|l|l|}
\hline \multicolumn{1}{|c|}{ Tahun } & \multicolumn{1}{c|}{ IPM } & \multicolumn{1}{c|}{ AHH } & \multicolumn{1}{c|}{ EYS } & \multicolumn{1}{c|}{ MYS } & Pengeluaran \\
\hline 2013 & 78,68 & 77,18 & 13,66 & 10,06 & 12713 \\
\hline 2014 & 79,24 & 77,18 & 13,97 & 10,19 & 12802 \\
\hline 2015 & 80,23 & 77,20 & 14,33 & 10,2 & 13588 \\
\hline 2016 & 81,19 & 77,21 & 14,7 & 10,49 & 13909 \\
\hline 2017 & 82,01 & 77,21 & 15,2 & 10,5 & 14334 \\
\hline 2018 & 82,72 & 77,23 & 15,5 & 10,51 & 14895 \\
\hline
\end{tabular}

Sumber : https://ipm.bps.go.id/data/kabkot/metode/baru/3374\#

Keterangan :

IPM = Indeks Pembangunan Manusia

$\mathrm{AHH}=$ Angka Harapan Hidup

EYS = Expected Years of Schooling (Harapan Lama Sekolah) atau HLS

MYS = Mean Years of Schooling( Rata-rata Lama Sekolah) atau RLS

Berdasarkan hasil perhitungan diketahui bahwa pertumbuhan IPM Kota Semarang dari tahun 2013 sampai dengan tahun 2018, adalah sebagai berikut.

$$
\begin{aligned}
\text { Pertumbuhan IPM } & =\frac{I P M \text { tahun } 2018-I P \text { tahun } 2013}{I P M \operatorname{tahun} 2013} \times 100 \\
& =\frac{(82,72-76,86)}{76,86} \times 100 \\
& =7,62
\end{aligned}
$$


Hasil dari perhitungan Indeks Pembangunan Manusia di Kota Semarang dari tahun 2013 sampai tahun 2018, mengalami pertumbuhan yang meningkat sebesar 7,62. Pertumbuhan tersebut cukup signifikan, dan terlihat ada relevansi antara peningkatan penggunaan media online berbasis web dengan perkembangan Indeks Pembangunan Mansuia di Kota Semarang. Berdasarkan data pertumbuhan IPM tersebut, dapat disimpulkan bahwa program yang diterapkan pada tahun 2013 sampai dengan tahun 2018 telah berjalan dengan efektif.

\section{Kesimpulan dan Rekomendasi Penelitian}

Berdasarkan hasil dari penelitian mengenai efektifitas penerapan konsep smartcity di Koat Semarang, maka diperoleh kesimpulan penelitian sebagai berikut :

1. Penerapan Konsep Smartcity di Kota Semarang dapat dikatakan cukup efektif. Hal ini dapat dilihat dari hasil kuesioner yang dilakukan oleh peneliti. Dimana hasilnya menunjukkan bahwa 75\% masyarakat Kota Semarang mengetahui dan sebagian lagi sebagai pengguna atau terlibat dalam program yang telah dilakukan oleh pemerintah.

2. Selain itu, dengan adanya program-program yang diterapkan pemerintah, membuat Indeks Pembangunan Manusia (IPM) Kota Semarang meningkat. Komponen tertinggi pembentuk karakter ini dibangun dari aspek smart society, yang telah mendorong percepatan interaksi masyarakat sehingga membentuk pertumbuhan ekonomi yang cukup tinggi.

Dari penelitian ini maka dapat disampaikan berbagai rekomendasi bagi pembangunan Kota Semarang sebagai berikut:

1. Perlu ditingkatkan kapasitas operasional perangkat daerah dalam mendorong aplikasi terapan di jenajng yang lebih bawah, seperti kecamatan dan kelurahan. Hal ini akan meningkatkan kualitas smart government, sehingga kinerja OPD maupun pelayanan di masyarakat semakin mudah.

2. Perlu dikembangkan berbagai instrument evaluasi lanjutan terhadap prioritasprioritas Pemerintah Kota Semarang dalam pencapaian suksesnya Kota Semarang sebagai Kota yang Cerdas (Smartcity).

\section{Daftar Pustaka}

Chandra Eko Wahyudi dan Muchamad Hariadi (Oktober 2016). Strategi Pembangunan Smart City dan Tantangannya bagi Masyarakat Kota. Jurnal Strategi dan Bisnis Vol4, No2, diambil dari 
http://repository.unej.ac.id/bitstream/handle/123456789/79312/4.\%20Chandra.pdf?s equence $=1$

https://bps.go.id/subject/26/indeks-pembangunan-manusia.html\#subjekViewTab2

http://dpmptsp.izin.semarangkota.go.id/index.php? $\mathrm{r}=$ site/online

https://semarang.merdeka.com/kabar-semarang/permudah-investasi-hendi-terus-doronginovasi-perizinan-1810152.html

http://smartcityiiuc.blogspot.co.id/

http://dotsemarang.blogspot.com/2017/10/perjalanan-semarang-smart-city-dari.html

Kompasiana. 25 Maret 2015. Landasan Hukum Inovasi Kota Cerdas. http://www.kompasiana.com/hendra budiman/landasan-hukum-inovasi-kotacerdas 552b1588f17e610d6cd623d4

Nurjati Widodo (2016). Pengembangan e-Government di Pemerintahan Daerah Dalam Rangka Mewujudkan Smart City (Studi di Pemerintah Daerah Kota Malang). JIAP (Jurnal Ilmiah Administrasi Publik). Vol 2, No 4, diambil dari http://ejournalfia.ub.ac.id/index.php/jiap/article/download/624/952

Peraturan Wali Kota Semarang No 26 tahun 2018 tentang Rencana Induk Semarang Kota Cerdas (Masterplan Semarang Smartcity)

Priskadini April Insani (April 2017). Mewujudkan Kota Responsif Melalui Smart City. PUBLISIA (Jurnal Ilmu Administrasi Publik). Vol 2, No 1, diambil dari jurnal.unmer.ac.id/index.php/jkpp/article/download/1423/909

Ryan Ezkirianto dan Muhammad Findi A (2013). Analisis Keterkaitan Antara Indeks Pembangunan Manusia Dan Pdrb Per Kapita Di Indonesia. Jurnal Ekonomi dan Kebijakan Pembangunan hlm. 14-29 Vol 2, diambil dari http://journal.ipb.ac.id/index.php/jekp/article/viewFile/19949/13741

Sariffuddin (2015). Peluang Pengembangan Smart City untuk Mewujudkan Kota Tangguh Di Kota Semarang (Studi Kasus: Penyusunan Sistem Peringatan Dini Banjir Sub Drainase Beringin). Jurnal TEKNIK, 36(1), 2015-32-38, diambil dari https://ejournal.undip.ac.id/index.php/teknik/article/view/7823/7085.

Sepdiano, Figi. 2015. "Pengertian IQ, EQ, SQ, AQ, CQ, dan ESQ".[online], (http://cycloxshare.blogspot.co.id/2015/09/pengertian-iq-eq-sq-aq-cq-dan-esq.html, diakses tanggal 15 Juli 2017). 